\title{
Modern Kültürde Kentten Kaçmanın ve Uzaklara Gitmenin Sosyolojisi
}

\author{
SERTAÇ TIMUR DEMIR* \\ stdemir@gumushane.edu.tr \\ ORCID ID: 0000-0002-9420-9416
}

\begin{abstract}
"Eğer toplum zorunluluk ve açgözlülüğün baskısı altında, doğanın armağanlarını ancak yırtıcı bir hırsla alacak, en yüksek karla satabilmek uğruna dalından ham meyvayı koparacak, karnını tıka basa doldurmak uğruna her çană̆ı sıyıracak kadar soysuzlaştıysa, o zaman dünya yoksullaşacak, toprak kötü hasat verecektir".
\end{abstract}

Walter Benjamin ${ }^{1}$

Öz: Bu makale bir tür kurtuluş reçetesine dönen doğaya bedensel, zamansal ve mekânsal deneyimler üzerinden odaklanmaktadır. Önceleri kent tarzı yaşamı arzulayan modern birey artık kentten sıkılmışv ve yeni arayışlar içine girmiştir. Bugün bu yönelimin merkezi doğadır. Bu açıdan uzak coğrafyalar üzerinde cereyan eden geri dönüş hikâyesini tartışmanın tam vaktidir. Çünkü büyük kentlere büyük hayallerle göç edenlerin beklentileri imtihan edilmiş, düş kırıklıkları yaşanmış ve yıllar sonra terkedilen eski köyler yeniden özlenmeye başlanmıştır. Bu bağlamda mazi ve hatıra mekânı olarak doğa ve taşra el değmemiş ve bozulmamış olarak tasavvur edilmiş ve kentin mutlak bir antitezi olarak benimsenmiştir. Burada beliren ana soru bakir ve arınmış doğanın kentleşmeyi merkezileştiren modern toplum figürasyonu tarafından kapsam dışı tutulup tutulmadiğı dır. Başka bir deyişle, kentte bunalan modern birey için doğaya kaçış ya da taşraya dönüş kalıcı bir çözüm mü yoksa geçici bir avuntu mudur? Tüm bu ikircikli sorunsallar bu çalışmanın çerçevesini oluşturmaktadır.

Anahtar kelimeler: Modernite, Kültür, Doğa, Kent, Kaçış.

\section{Giriş}

Kentleşme yöneliminin doyuma ulaştığı ve soluk almanın bile kentliler arasında bir tür bıkkınlık halini (blasé attitude) ${ }^{2}$ aldığı bu yüzyılın yeni gündemi yeniden doğa’dır. Bugün pastoral çağa özlem ve taşraya öykünme şeklinde vücut bulan bu yöneliş, kentin bireyin mental yaşamını aşındırdığı ve onu varlık özünden uzaklaştırdığı

\footnotetext{
* Yrd. Doç. Dr., Gümüşhane Üniversitesi, İletişim Fakültesi.

1 Walter Benjamin, Tek Yön, çev. Tevfik Turan. İstanbul: Yapı Kredi Yayınları, 2011, s.62.

2 Georg Simmel, Bireysellik ve Kültür, çev. Tuncay Birkan. İstanbul: Metis Yayınları, 2009, s.321.
} 
varsayımına eşlik etmektedir. Doğa sosyolojisi olarak da kavramsallaştırılabilecek bir alt-disiplinin yükselmesine öncülük eden bu kültürel değişim, medyadan tüketim alışkanlıklarına geniş bir yelpazeyi etkilemekte; öyle ki organik olduğu varsayılan bir yaşam tarzını tayin etmektedir. Taklit olan her şeyi mutlak olanın yerine koyan kültür endüstrisinin ${ }^{3}$ eleğinden geçirilen bu yeni tip doğal olmayan doğa tasavvuru göz alıcı ama içi boşaltılmış, dahası yalnızca yüzeylerden ve sunumlardan ibaret bir simülasyondan başka bir şey değildir.

Kalabalık kent yaşamına koşut olarak yaşanan çevresel ve toplumsal bozulmalar, kentliler arasında taşra çağrışımları yüksek kurgusal ve dekoratif bir köy hayalini harekete geçirmektedir. Zamanın olanca biçimsiz ve belirsiz bir akışkanlıkla harcandığı kentte doğa ve doğallık böylece bir tüketim nesnesi olarak pazarlanabilmektedir. Yeni bir piyasa fikri olarak körpe doğa, yalın köy, içten köylü ve organik tarım ve hayvancılık söylemleri etrafında önü alınamaz bir sektörün öncülüğünü yapmaktadır. Yüksek güvenlikli, steril ve lüks konutların dahi bir tür köy taklidi formu içinde pazar bulduğu bu ikircikli koşullar altında kent, gerçekten Walter Benjamin’in iddia ettiği gibi $^{4}$ gezilen değil; daha çok satın alınan bir mekansallığa gönderme yapmaktadır. Böylece en lüks siteler bile köy tarzı mimarisiyle -örneğin site içi ağaç monteleme, yapay göller ve dereler üzerinden- doğa özlemini bastırmayı hedefleyen birer temsiliyet olarak tasarlanmaktadır.

'Mis gibi' doğa imgesi burada 'mış gibi' yapma edimine evrilmektedir. Böyle olduğu için, kentte doğa simülasyonunda ruhlarını avutanlar çeşitli bitki ve hayvan türüyle iç içe yaşasalar da, onlar hakkında çok az şey bilirler ${ }^{5}$. Gerçek doğa, kent içinde bilgiden çok anlam ve hikmetten yoksun bir oluşla kitlesel üretime entegre sembollere indirgenir, fiyatlandırılır, satışa sunulur ve tüketilir. Burada yanılsamalı olarak bir tek ağaç, ormanı; bir demet çiçek, bahçeyi; bir koku, dağ esintilerini; bir tek kelime de taşra duygularını karşılar. Bu noktada her şey doğalı ima ederken; her maddi yönelim doğa üzerinden hem fetişleştirilir ${ }^{6}$ hem de gizliden gizliye meşrulaştırılır. Simmel haklıdır: "Kent hayatı, insanın hayatta kalmak için doğayla giriştiği mücadeleyi, insanlararası kazanç mücadelesine dönüştürmüştür. Buradaki kazanç doğadan değil; başka insanlarda elde edilir"”.

\section{Çerçeve ve Yöntem}

Son zamanlarda sıklıkla kentsel yaşamın yergisi yapılırken; modern teknolojik bireyin çağdaş ağıtı yakılmakta ve herkes bakir olarak varsayılan doğaya davet edilmektedir. Bir tür popüler kültür eleştirisi yapan bu popüler söylem bu makalenin çıkış noktasını ve eleştiri eksenini tayin etmektedir. Genel anlayışa göre kent, hakkında eleştiri yapmanın tüm yollarının sonuna kadar açık olduğu yozlaşmayı ve kayıtsızlığ

\footnotetext{
3 Theodor W. Adorno, Kültür Endüstrisi - Kültür Yönetimi, çev. Elçin Gen, Nihat Ülner, Mustafa Tüzel. İstanbul: İletişim Yayınları, 2016.

4 Benjamin, Tek Yön, s.79.

5 Yi-Fu Tuan, Bir Kurucu Unsur olarak Kaçış, çev. Şevket Emek Ataman. İstanbul: Litera Yayıncılık, 2015, s.47. 6 Henri Lefebvre, The Urban Revolution, Minneapolis: The University of Minnesota Press, 2003.

7 Georg Simmel, Modern Kültürde Çatışma, çev. Tanıl Bora, Utku Özmakas, Nazile Kalaycı, Elçin Gen. İstanbul: İletişim Yayınları, 2015, s.98-99.
} 
ifade ederken; doğa da kentin diyalektiği olarak kusursuz güzelliği ve öze / maziye dönüşü portrelemektedir. Böylece esasen doğanın iyileştirici etkisi vurgulanırken; kentleşme üzerinden bir tür modernite eleştirisi sunulmaktadır. Yani modernitenin açmazlarını somutlaştıran kent-eksenli gerilimler yeni bir mekân arayışını ya da doğaya dönme düşüncesini yüceltmektedir. Yine de bir manifesto şeklinde ele alınan bu karşıt anlatının umut ve heyecan verici olmakla birlikte, ne denli isabetli ve gerçekçi olduğunu da tartışmak gerekmektedir.

Kaçma ya da doğaya geri dönmekle ilgili iç açıcı hayalin ödenmeyi bekleyen bedelleri yok mudur? Doğanın çağrısına kulak vermenin ve geriye doğru göçün gerekliliği bir tarafa, bunun imkânlarını oluşturmak adına birikmiş kentli birikimleri bir hamlede silmek ya da yok saymak kolay mıdır? Sorgulamasız bir önkabulle benimsenen doğanın sıcaklığı, içinde hayatta kalmanın bile bitmeyen mücadeleler silsilesi fikrini neden ve nasıl bastırmaktadır? Yani doğa, içinde hiçbir gücün ve güçlügün olmadığı bu kadar steril ve nostaljik bir mekan mıdır gerçekten? Zaman orada tümüyle her an yenilenmeye imkân tanıyan bir çizgisellik içinde midir; yoksa kendi içine kapalı mental yapıdaki bireylerin önünde tekrarcı bir döngüsellik mi arzetmektedir? Başka bir deyişle, mekânın ve zamanın genişlemesi ${ }^{8}$, gerçekten bir çoğalma, bereketlenme ve içi doldurulabilir eylemlerin imkânlılığ $1 \mathrm{ml}$; yoksa bir tür zamansal ve mekânsal hiçleşme ve boşluğa düşme hali midir? Bu makalede, kent yaşamı eleştirilse de; doğaya da mutlak bir olumlama yüklenmemektedir. Teorik tartışmanın yapıldığı ve literatürel taramasına dayalı bu çalışmanın teorik çerçevesi Charles Baudelaire, Walter Benjamin, Gaston Bachelard, Yi-Fu Tuan ve Rasim Özdenören gibi esaslı düşünürlerin eserleri eksenine yerleştirilmiştir.

\section{Kent Eleştirisi}

Pratiklik ve erişilebilirlik yönüyle öne çıkan kent mekânı, bu açıdan Alain de Botton'un vurguladığ 1 gibi ${ }^{9}$ eski zaman insanlarının aksine, çok fazla şeyi fakat tümüyle yüzeysel öğrenen ve yaşayan; hiçbir şeye yeterince hayret edemeyen ve minnettarlık hissini yitirmiş bireylerin hem kaotik hem de belirsiz dünyasını ifade etmektedir. $\mathrm{Bu}$ durum apartman mimarisiyle somutlaştırılabilir. Yani kentte olmanın eşzamanlı iticiliği ve çekiciliği biraz da apartmanda ikamet etmenin güvenli fakat zevksiz tabiatında karşılık bulur. Modern kentliler gibi apartmanlar sakinleri de zamanla aynılaşırlar. Benzer zevklere, benzer endişelere ve benzer meşgalelere hapsolurlar. Paul Claudel ve Max Picard'ın görüşlerinden beslenen Bachelard, kenti ve kentteki evin imkânsızlığını tipik bir kent modeli olan Paris üzerinde şu sözlerle açıklar:

Paris’te ev yoktur. Büyük kentte oturanlar, üstüste konmuş kutularda yaşarlar... Sokak numarası, kat numarası, bize ait bu saymaca deliğin yerini belirler; ne var ki konutumuzun çevresinde ne bir uzam vardır, ne de kendi içinde bir dikeylik... Evin kökü yoktur... Odalar, kaldırımdan çatıya kadar üst üste yığılır; ufku olmayan bir gökyüzü, çadır bezi gibi örter tüm kenti. Kentteki yapıların

8 David Harvey'in zaman-mekan sıkışması tartışmasına gönderme yaparak. Bkz. David Harvey, Postmodernliğin Durumu, çev. Sungur Savran. İstanbul: Metis Yayınları, 1999, s.174-177.

9 Alain de Botton, Çalışmanın Mutluluğu ve Sıkıntısı, çev. Süha Sertabiboğlu. İstanbul: Sel Yayıncılık, 2014, s.37. 
yalnızca dış yüksekliği vardır... Evim denen yer de, basit bir yataylıktan başka bir şey değildir. Bir kata sıkışmış konutun farklı odaları, mahremiyet değerlerini ayırt edecek ve sinıflandıracak temel ilkelerin birinden yoksundur. ${ }^{10}$

Mimari düzeyde yalnızca dış’n olduğu bir uzamda, toplumsal ilişkiler yalnızca yüzeyler üzerine kuruludur ve oradaki bireyler de yalnızca bedensel görünümlerine indirgenmektedirler. Dolayısıyla burada hayaller ve idealler değil; planlar ve hedefler öne çıkmaktadır. Doğada hayatta kalmayı ifade eden insani çaba, kent yaşamında belli bir kesintisizlik içinde hep daha fazlasını elde etme hırsına dönüşmektedir. Oysa Chul Han'ın da Cicero’nun felsefesini anlatırken belirttiği gibi "kişiyi olması gerektiği kişi yapan tek şey faal hayat değil, düşünceye dalmış bir hayattır" "ve bu durum, bireyi sükûnetin ve inzivanın mümkün olduğu doğaya sığınmaya -ya da en azından bulunduğu yerden ayrılmaya davet etmektedir. Çünkü silikleştiren yoğun imgeleriyle kent mekânı, benliği alabora eden akışkanlığına bağlı olarak zamanın bunaltıcı boyut kazandığı bir yaşam alanıdır. Hem artık geçerli bir zaman ölçeği kalmadığından şikâyet eden ${ }^{12}$ ve hem de zamanın hayatı yediğini düşünen Baudelaire'in ${ }^{13}$ aksine; kentte asıl olarak amorf hayat zamanı tüketmektedir. Enerji kaynaklarının yetmemesi, işsizlik, konut problemi, ulaşım ve hava kirliliği gibi gözle görülür riskli faktörlerin varlığı bu gerçeği doğrulamaktadır. Ne var ki, kentten kaçma adresi olarak doğa modernliğin tüm açmazlarına çözüm getirebilir mi? Daha önemlisi, bu haliyle doğa modern bireyi arzular mı?

Nietzsche için mutluluk doygunluktan çok; bir kuvvetin büyüdüğü ya da bir engelin aşıldığı duygusudur. ${ }^{14}$ Oysa hayattaki tüm engelleri aşmanın kendi başına bir engelleme olduğu ve bireyi başka türlü bir anlamsızlığa sürükleyeceği unutulmamalıdır. Öte yandan doğa, sayısız ve ardı arkası kesilmeyen engellerle örülüdür ve gücü de esasında bu engellerin kesin ve kalıcı olarak aşılamayacak olmasındadır. Bu nedenle bireyin kendi dışındaki dünyaya indirgediği bir mutluluk yönelimi distopik bir tavırdır. Kentle doğa arasında tanımlanagelen ikilik de bu nedenle biraz da muğlaktır. "Belirsizlikten kaçma umuduysa insan yaşamındaki arayışların motorudur. Belirsizlikten kaçmak yalnızca zımnen varsayılsa bile her türlü karma mutluluk hayalinin en önemli bileşenidir. Gerçek muntazam ve eksiksiz mutluluğun her zaman belli bir uzaklıktaymış gibi görünmesinin nedeni de işte budur: malum ufuk gibi, ne zaman yakınlaşmaya çalışsanız uzaklaşır”'15 İnsanoğlu, Tuan’ın dediği gibi, orada olmayanı 'görme’ye istidatlı tek varlıktır. ${ }^{16}$ Doğanın doğal olduğunu görmek de bu cinsten bir görme olabilir mi? Yani sahiden köy özgür; taşra uzak ve doğa da doğal mıdır?

10 Gaston Bachelard, Uzamın Poetikası, çev. Alp Tümertekin. İstanbul: İthaki Yayınları, 2008, s.65-66. 11 Byung-Chul Han, Yorgunluk Toplumu, çev. Samet Yalçın. İstanbul: Aç1lım Kitap, 2015, s.35.

12 Charles Baudelaire, Şarabın Şiiri \& Esrarın Şiiri, çev. Orhan Düz. İstanbul: Dedalus Kitap, 2014, s.78.

13 Charles Baudelaire, Kırk Kötülük Çiçeği, çev. Ahmet Necdet. İstanbul: Broy Yayınları, 2000, s.15.

14 Friedrich Nietzsche, Deccal Sahte İsa, çev. Yusuf Kaplan. İstanbul: Külliyat Yayınları, 2017.

15 Zygmunt Bauman, Yaşam Sanatı, çev. Akın Sarı. İstanbul: Versus Kitap, 2016, s.36.

16 Tuan, Bir Kurucu Unsur Olarak Kaçış, s.26. 


\section{Doğanın Doğallığı Üzerine}

Doğada olmak fikri, kentli bireyin dinginlik dışında biraz da macera istencine karşılık gelmektedir. Maceracı olmak, Simmel’e göre, düzenin ve alışkanlığın bir şekilde tersyüz edilmesidir. ${ }^{17}$ Yani macera ancak mekânın içinden gelip geçme, geçerken de yeni deneyimler üretme ve bu deneyimlerle bilindik rutinleri kırma girişimidir. Üstelik maceracı, tüm dikkat ve eylemini geçmişin korkularından ve geleceğin beklentilerinden arındırarak; yalnızca şimdi’de toplamaktadır. Çünkü o, yeryüzünü insanın kalıcı evi değil; geçici sığınağı olduğunun bilincindedir. ${ }^{18}$ İçinde bulunduğu mekâna ve sahip olduğu ilişkilere hassasiyetle ve fanilik şuuru içinde yaklaşan bir misafir gibi davranmaktadır. Bu nedenle maceracının, içinde bulunduğu ama içine nüfuz edemediği doğayla kurduğu ilişki de yakınlık görünümünün yanında mental bir uzaklığ 1 da ihtiva etmektedir. Öte yandan doğanın içinden gelip geçen maceracı arayışını bir kenara koyarak her gün her saat doğada kalsa, yani hikayesini anlatmak zorunda olduğu kentli izleyicileriyle bağını tümüyle koparsa doğanın bir parçası olabilecektir. Ancak bu durumda da yaşamı belki bir kentlininkinden bile yoğun tekrarcılık içinde sıkıcı eylemler silsilesine kilitlenecektir.

Böyle olunca, doğa muhtemelen tüm albenisini ve egzotiklik değerini de yitirecek ve çetin yaşam koşullarının hüküm sürdügü bir tür döngüsel hayatta kalma mücadelesi baş gösterecektir. Daha açık bir ifadeyle, doğaya çıkmak heyecan verici bir fikirse de; doğada kalmak zor ve çelişkili bir karardır. Sokak müziği yapan Siya Siyabend adlı grubun üyelerinden birinin Fatih Akın’ın 2005 yılında yaptığı İstanbul Hatırası: Köprüyü Geçmek belgeselinde söylediği sözler bu anlamda dikkat çekicidir. Çünkü sokak ve taş üzerine söylenmiş bu sözler doğayla ilişkilendirilmeye açık bir analoji barındırmaktadır: "Sokak hemzemin oluşundan dolayı insanı birleştirir. Hangi s1nıfsal temelden olursan ol, bütün insanları aynı hizaya getirebilir; böyle bir özelliği vardır sokağın. Ama diğer taraftan da sokak aslında ağır bir yozlaşmadır. Buna karşı koymak... Sokağın belleğinden bahsedemeyiz yani taşın belleğinden. Erkin Koray Ankara sokaklarından, kaldırımlarından bahsederken bu çok romantik bir şeydir. Bunu yaşayan adam bilir. Taş taştır! Oraya kafayı koyduğun zaman anlarsın taşın taşlı̆̆ını”.

Maceracının kaldırımlardan ya da doğadan gelip geçerken veya kısa süreliğine turistik bir girişimcilikle orada sınırlı bir süre kalarak anlayabileceği şey onun yalnızca ilgi uyandırıcı yüzeyidir. Birkaç günlük nostaljiyi aşmanın yoluysa, kentten mekânsal ayrışmanın bir adım ötesinde, esasında kentli ruh halini askıya almaktır. Bugün kablosuz internet ağı (Wi-Fi) arama teşebbüsünden vazgeçme olarak da ifade edilebilecek bu uzaklaşma, taşın sert ve soğuk olduğunun kesin bir kabulüne de dayanmalıdır. Bu nedenle Bukowski’nin dediği gibi, "heves yeterli değildir değişmek için. Adımlar doğal olmalı ve hayatın içinden gelmelidir”. ${ }^{19}$ Sürekli teyakkuzda olmayı zorunlu kılan tehditlerden arındırıldığı sürece doğa, insan için gerçek olmayan dekor ya da seyirlik bir manzaradan başka bir şey değildir. Bu yönüyle rüzgârın 1sitıcı, yağmurun dinlendirici, hayvanların dost ve çiçeklerin de ferahlatıcı olduğu düşünmek

17 Simmel, Bireysellik ve Kültür, s.186.

18 Simmel, Bireysellik ve Kültür, s.190.

19 Charles Bukowski, Kahramanın Yokluğu, çev. Avi Pardo. İstanbul: Parantez Yayınları. 2015, s.160. 
ve düşündürmek bu açıdan sorunludur. Oysa Tuan'ın işaret ettiği gibi doğada rüzgâr üşütücü, yağmur perişan edici ve sarmaşıklar zehirli olmadığı sürece o doğa gerçek doğa değildir. ${ }^{20}$

Benzer şekilde, apartmanlardaki kalorifer teknolojisi zahmetsiz ısıtıcıdır; ne var ki ev içindeki bireyleri birbirinden uzak odalara sevk eder ve birbirini sevenler arasındaki bedensel mesafeyi meşrulaştırır. Oysa doğadaki ateş bir araya getirici; etrafındaki dağınık -hatta birbirini tanımayan kalabalıkları yakınlaştırıcıdır. Bu nedenle ateş, Bachelard'ın tasvir ettiği gibi, doğaldan çok toplumsal bir varlıktır. ${ }^{21}$ Buna rağmen ateş sıcaktır ve yakıcıdır. Kendisiyle kurulacak ilişkide devamlı dikkat ve tedbiri zorunlu kılmaktadır. Bu ön ve daimi koşul, güvenli barınma, hızlı beslenme ve moda tarzı giyinme kültürünü içselleştirmiş pratik modern birey için güvenilmez, yavaş ve çağdışı bir yönelimdir. Hiç şüphesiz tabiat kanunlarından çok ekonomik ilişkilerin belirlediği kent ortamında talihsizlikler her an tetikteyken; tehdidin hangi yönden, ne zaman ve ne büyüklükte geleceği kestirilemezdir. Bunun karşısında doğa da korku ve şiddet niteliklerinin tümüyle yok sayılamayacağı bir güvensizliği mimlemektedir. ${ }^{22}$ Yine de kentten kaçma ediminde geçerli motivasyon, varılacak yerin güvenirliliğinden ziyade kendisinden kaçılan mekanın kaçan öznede kışkırttığı duygudur. Başka bir ifadeyle, kaçmak mekân ve araçtan çok özneye dair bir duygulanıma eşlik etmektedir.

Kaçmak ya da uzaklaşmak varlığın bedensel devinimini gerektirse ve ona koşutmuş gibi görünse de; esasında varlığa içkin bir durumu ifade etmektedir. Bu durumda kişi en çok da en fazla yakın olduğu şeye uzaktır ya da en uzakmış gibi göründügüü şeye yakındır. Çünkü onun içselliği kendinden uzak olanın, bu durumda bir kentli için doğanın ya da bir taşralı için kentin kusursuzluk algısı -esasında yanılgısıyla doludur. "Ben nerede değilsem orada iyi olacakmışım gibi gelir" diyen Baudelaire de ${ }^{23}$ bu çelişkiyi anlatmaktadır. Bulunulan yerden ayrılma, uzaklaşma ve uzaklaşma eylemi bu bağlamda içsel mutsuzluk halinin yansıması ve sonucudur. Rasim Özdenören de benzer şekilde, kendini değiştiremeyenin bir avuntu olarak kentini değiştirmeye yöneldiğinden bahsetmektedir. ${ }^{24}$

Öte yandan, eğer kentlilik mekânsal çerçevenin ötesinde bir yaşam biçimi ya da ruh haliyse -ki esasında tam da böyledir, öyleyse kentli, gittiği her yeri kentlileștirme eğilimiyle karşı karşıyadır. Doğaya yönelmek, bu nedenle içinden yalnızca gelip geçenler için kentin dişında olan ancak sonuna kadar kentli bir tecrübeyi ifade edecektir. Ayrıca, kentlilik rahatsızlığı karşısında bir tür vicdanı temize çekme veya tabiri caizse bir günah çıkarma teşebbüsü olacaktır. Bu nedenle bana göre kaçış, ancak bir amaç içermiyorsa sonuç verebilir. Başka bir deyişle, kentli tavrın antitezi olarak doğayı hedefleme yine kentli, kentle ilgili ve kenti yeniden üretici bir karardır.

Benzer çelişki, yaşamını tümüyle doğayla iç içe ve doğadan temin edenler için de geçerlidir. Tanıl Bora kentin taşralaşırken; taşranın da kentleştiğini ve böylece taşra

20 Tuan, Bir Kurucu Unsur olarak Kaçış, s.26.

21 Gaston Bachelard, Seçmeler, çev. Afşar Timuçin. İstanbul: Remzi Kitabevi, 1988, s.17.

22 Tuan, Bir Kurucu Unsur olarak Kaçış, s.31.

23 Charles Baudelaire, Flowers of Evil and Other Works, s.150.

24 Rasim Özdenören, Kent İlişkileri, İstanbul: İz Yayıncılık, 2015, s.82-83. 
mahremiyetinin aşındığını öne sürmektedir ${ }^{25}$. Bu tespit yanlış değildir; ancak asıl dönüşüm, bireylerin iç dünyalarında cereyan etmektedir. Buna göre kentliler taşralılaşırken; taşralılar da kentlileşmektedir. Üstelik bu paradoks, hem mentalite hem de tüketimcilikle ilgilidir. Merkezin kaçış güzergâhı, uzak taşra iken; taşranın ufku da merkezdir. Taşra ve kent sıkıntısının kışkırttığı bu yer değiştirme durumunda taşra sıkıntısı kentte de yaşanabilecek bir deneyim olan dışta kalmayı, eve kapanmayı ya da daralmayı ifade ederken ${ }^{26}$; kent sıkıntısı da bir tür kontrolsüz izolasyonu, kaybolmayı ve ölçüsüz genişlemeyi mimlemektedir.

Dünya da bir yandan gittikçe bölünen, gettolaşan, keskinleşen, kutuplaşan ve savaşan karşıt anlayışların dünyasıyken; diğer yandan da kitle iletişim araçlarının, medyanın, reklamın, internetin ve dijital platformların eriştiği her yerde belirgin bir grileşme ve aynılaşmaların da dünyasıdır. Bu bakımdan, doğanın içinde yaşayanlar, kentlilerin öykündüğü doğal yiyecekler ve gösterişsiz kıyafetlere sahip olsalar da -ki böyle olduğunun düşünülmesi biraz da klişedir, hiç değilse hayalleriyle, arzularıyla ve özentileriyle kentlilerdir. Daha çok kentli olan kültür, Tuan’ın da saptadığı gibi, ${ }^{27}$ günümüzde doğaya üstün gelmiştir: "Gerçek, kültürel olandır. Kültürel olan, çok fazla insan yapımı gibi görünmeden, ruhani veya ilahi görünerek doğal olana baskın çıkmakta ve böylece kozmik kent, yaban hayattan daha gerçek olmaktadır"28. Balta girmemiş mekanların ve samimi ilişkilerin yurdu olarak varsayılan doğa, bir kesime göre fantastik bir umut; diğerleri için kapitalizme entegre sonu gelmez bir hammaddeyse de; her ikisi için birden el değmemişliğinin gerisinde güncel bir özel mülkiyet sorunsalının orta yeridir. Bu sebeple, kaçışın ve uzaklara gitmenin sürdürülebilirliği yok gibidir. Kentliler, gittiği her yere başka kentler inşa etmeye meyillidir. ${ }^{29}$ Bunun çözümü esasında benliğinin içine eğilmek ve en büyük mücadeleyi burada yürütmekken; fenomenler dünyasına dönük çelişkili bir yöneliş belirmektedir:

Doğa özlemi çektiği söylenen kimse, şimdiye kadar kendini doğadan yalıtıp durmadı mı? ... Barınaklar inşa ederek doğadan kurtulmak istemedi mi? Kendine durmadan yeni aletler icat ederek eliyle doğa arasına sınırlar çekip durmadı mı? ... Öyleyse doğayı özlediğini söyleyen biri, acaba bir duygusunu yanlış mı ifade ediyor? Yoksa o ne istediğini mi bilmiyor? ... Gövdesini doğadan yalıtmak için gene bir şeyler giymek zorunda kalmayacak mı bu insan? O, yapraklarla mı örtünmek istiyordu; otlardan dokunmuş giysilerin mi özlemiyle yanıp tutuşuyordu? ${ }^{30}$

Yine de doğa, henüz tam anlamıyla tüketilmemiş ve her şeye olmaya hazır olduğu ümit edilen bir yerdir. Doğaya atfedilen olumlu ve yapıcı niteliklerin kentli karakterin tam da sahip olmadığı şeyleri tamamladığı düşüncesi bu ümidin asıl kaynağıdır. Doğa kentli için bir tür tamamlanma ve fazlalıkları atma vaadi taşımaktadır. Bu

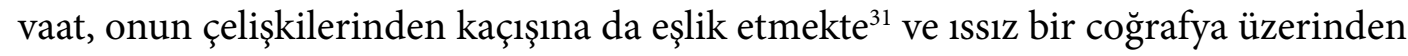

25 Tanıl Bora, Taşraya Bakmak, İstanbul: İletişim Yayınları, 2013, s.44-45.

26 Nurdan Gürbilek, Yer Değiştiren Gölge, İstanbul: Metis Yayınları, 1995, s.50.

27 Tuan, Bir Kurucu Unsur olarak Kaçı̧s, s.44.

28 Tuan, Bir Kurucu Unsur olarak Kaçı̧, s.45.

29 Özdenören, Kent İlişkileri, s.82.

30 Özdenören, Kent İlişsileri, s.80-81.

31 Henri Lefebvre, Modern Dünyada Kültürel Hayat, çev. Işın Gürbüz. İstanbul: Metis Yayınları, 2010, s.85. 
dingin fakat düşsel bir dünyanın kapılarını aralamaktadır. Ne var ki bu, coşkuyla başlayan bu yakınlaşma zamanla yerini sıkıcı tekrarlara ve yeni arayışlara bırakmaktadır. Bir sonraki aşamada muhtemelen ya doğa insana ya da insan doğaya zarar vermeye başlamakta -ki bu, birbirini tüketen tarafların hayatta kalma savaşına dek sürmektedir. Neticede doğa da insana muhtaçtır. İnsan ve doğa arasındaki alışverişin bir tarafında doğanın sağladıkları, öte tarafında ise olanca bozgunculuğuna rağmen insanın tanımlayıcı ve kültür tasarlayıcı gücüne duyulan mutlak gereksinim vardır. Çünkü doğa ancak insanın ona verdiği -çoğu kez lirik değerle kendisini yeniden ve gerçekten üretebilmektedir.

Doğanın ve uzak taşranın çekiciliği, onun aynı zamanda iticiliğini içermektedir. Kalabalık olmayan ve tanıdıklardan oluşan insanlarla ve aşina bir çevreyle kuşatılmış olmak hem özgürleştirici hem de esir edici bir durumdur. Az ve tümüyle tanıdıktan oluşan bir kitle, Elias Canetti’nin ifade ettiği gibi düşünülebilecek en korkunç kitledir. ${ }^{32} \mathrm{Bu}$ yönüyle doğanın temin ettiği genişlik ve ferahlama hissi yanıltıcı ve katastrofik olabilmektedir; öyle ki kaçış eyleminin kendisi bile öznenin belirlediği bir teşebbüsün ötesinde; bugün kentleşme kalıpları ya da kültür endüstrisinin ürettiği bir trenddir. Adorno haklıdır: "En pratik şeydir kaçış, büyük sermayenin en hararetle benimsediği şey: Uzaklara kaçılırız... Mesajla doludur kaçış. Karşıtı olan mesaj da gerçekte olduğu şeye benzer: Kaçıştan kaçma isteği. Şeyleşmeye karşı direnci şeyleştirir" ${ }^{33}$ Kendi karşıtını da kendi üreten bu endüstrinin gölgesinde uzaklık, özgürlük ve doğallık göndermeleri, bu nedenle kentin karşısında değil; daha önce vurgulandığı gibi, kentle birlikte ama daha yüce totaliter bir iktidar şemasının altında aynı amaca hizmet etmektedir.

Žižek'e göre de, kaçışın ya da doğaya dönmenin olasılığını düşünmek bile yıkıcı bir yanılsamadır. ${ }^{34}$ Yıkıcıdır, çünkü ona göre tüm bütün büyük kitlesel cinayet ve soykırımların arkasında kendi içinde antagonizmalar barındırmayan, uyumluvarlık-olarak-insan vardır. Yanılsamadır, çünkü yine ona göre insanın kendisi zaten 'doğanın yarası'dır ve yapabileceği tek şey bu gediği, bu yarığı, bu yapısal köksüzlüğü kabullenmek ve ondan sonra da şeyleri mümkün olduğunca onarmaya çalışmaktır. Bu yönüyle, göçebelikten yerleşikliğe; oradan kentleşmeye ve şimdi de yeniden göçebeleşmeye ve doğaya dönmeye dair gösterdiği çaba, modern insanın trajedisidir. Doğanın tıpkı asırlar önce terkedildiği haliyle kaldığı -gerçekdışı ya da kurgusal varsayımı ise bu trajedinin belki de en ironik bölümüdür. Kaçışın kusursuz mekânı ve zamanı yoktur; aksine kaçışın kusursuzluğu onun dışsal bir amaca, mekâna ve zamana körleşmesindedir.

\section{Sonuç}

Kendi içinde kaçış fikrini kışkırtan sayısız yıkıcı unsura karşı mücadele eden modern kentli için uzak ve issız bir yerlere gitme fikri, bugün oldukça popüler bir konu ve bir

32 Elias Canetti, İnsanın Taşrası, İstanbul: Payel Yayınevi, 2011, s.215.

33 Theodor W. Adorno, Minima Moralia, çev., Ahmet Doğukan ve Orhan Koçak. İstanbul: Metis Yayınları, 2005, s.208.

34 Slavoj Žižek, İdeolojinin Yüce Nesnesi, çev. Tuncay Birkan. İstanbul: Metis Yayınları, 2011, s.21. 
moda unsurudur. Nitekim yıllar önce birçokları gibi merkezin cazibesine kapılarak taşrasından kopan yeni-kentliler burada aradıklarının bir kısmını bulmuş olsalar da, geçmişten getirdikleri kültürel mirası ve geleneği zamanla yitirmiştir. Başka bir deyişle, bir tür beton - toprak karşıtlığıyla metaforize edilebilecek bu ikilemde modern kentli önce betona öykünmüş, onun için ve onun içinde yaşamış ve sonunda en korunaklı ve gösterişlisinden beton yapıları mülkiyetine geçirmiştir. Ne var ki hızlı ve kısa denebilecek bir zaman sonra varlığının köklerine sinen 'toprak'ın yoksunluğunu duyumsamıştır. Böyle olduğu için bugün hemen her kentli, hiç değilse emekli olduktan sonra geride ve geriye kalan tek ve belki de son plan olarak köyüne, toprağına geri dönmeyi planlamaktadır.

Bu planın içi, doğayla iç içe köydeki müstakil evin bahçesinde katkısız sebze meyveler yetiştirmek ve hayvanlar beslemek; onların yapaylaştırılmamış, dondurulmamış, fiyatlandırılmamış ve piyasaya düşmemiş nimetlerinden faydalanmak fikriyle yüklenmiştir. Beri yandan, kentten kaçıp doğa simülasyonu içinde huzur arayan modern bireyin kaçınılmaz olarak yakalanacağı başka türlü bir ruh hali, bir karakter formu ve bir yaşam biçimi olarak kentlilik vardır. Tavrına ve bakışına sinen bu kentlilik hali, doğadaki her şeyi kentle irtibatlandırmayı ve karşılaştırmayı; ona verdiği değerde de kenti ölçü almayı şart koşacaktır. Tam da bu nedenle doğa, iddia edilegeldiğinin aksine, kaçış menzili olarak sınırsız kopuşun ve koşulsuz özgürlüğün mutlak adresi olamayacak kadar kentle ilintilidir. Öyle ki içinde bulunduğumuz kırılgan ve akışkan modernitede doğa, çürütücü kenti sağaltabilecek bir antitez olmak bir yana; belki de onu yeniden üreten bir bileşen işlevi görmektedir.

Bugün kesin ve mukim dönüş adresi olmayan bir maceraya çıkmak muhaldir. Çünkü hakkında hemen her şeyin önceden kestirilebildiği ve kontrol edilebildiği bir ileriki zaman yolculuğundan yepyeni ve tamamen farklı bir izlenim çıkamamaktadır. Nitekim modern insan tüm sıradışı olasılıkları belirli bir önbilgi olarak tanımış ve olası her macerayı henüz daha başlamadan tüketmekte ve sıradanlaştırmaktadır. $\mathrm{Bu}$ yüzden maceranın hayali canlı; kendisi ölüdür. Doğaya kaçmak ve burada kente nispeten inzivaya çekilmek, bireyin sterilize edilmiş bir coğrafyada ama kendisi ile kalabalıklaşmasına neden olmaktadır. Burada ve bu anda çözümler üretip kararlar alınsa da; çözümleri hayata geçirecek stabil bir zemin bulunamamaktadır. Doğada kalan insan, geçici bir sükûnet ve iç huzur halinde olsa da, hem kendisine hem de çevresine yönelik yapılandırılması ve harekete geçirilmesi beklenen mücadele mekanizmasının dışında kalmaya mecburdur. Doğanın içinde ama hayatın dışında kalma yazgısı, kaçışla ya da doğaya dönüşle ilgili kusursuz hayalin ödenmeyi bekleyen belki de en gerçekçi bedelidir.

\section{Kaynakça}

Adorno, Theodor W., Kültür Endüstrisi - Kültür Yönetimi. Çev., Elçin Gen, Nihat Ülner, Mustafa Tüzel. İstanbul: İletişim Yayınları, 2016.

Adorno, Theodor W., Minima Moralia. Çev., Ahmet Doğukan ve Orhan Koçak. İstanbul: Metis Yayınları, 2005.

Bachelard, Gaston. Seçmeler. Çev., Afşar Timuçin. İstanbul: Remzi Kitabevi, 1988. 
Bachelard, Gaston. Uzamın Poetikası. Çev., Alp Tümertekin. İstanbul: İthaki Yayınları, 2008.

Baudelaire, Charles. Flowers of Evil and Other Works. New York: Dover Publications, Inc., 2013.

Baudelaire, Charles. Kırk Kötülük Çiçeği. Çev., Ahmet Necdet. İstanbul: Broy Yayınları, 2000.

Baudelaire, Charles. Şarabın Şiiri \& Esrarın Şiiri. Çev., Orhan Düz. İstanbul: Dedalus Kitap, 2014.

Bauman, Zygmunt. Yaşam Sanatı. Çev., Akın Sarı. İstanbul: Versus Kitap, 2016.

Benjamin, Walter. Tek Yön. Çev., Tevfik Turan. İstanbul: Yapı Kredi Yayınları, 2011.

Bora, Tanıl. Taşraya Bakmak. İstanbul: İletişim Yayınları, 2013.

Botton, Alain de. Çalıșmanın Mutluluğu ve Sıkıntısı. Çev., Süha Sertabiboğlu. İstanbul: Sel Yayıncilik, 2014.

Bukowski, Charles. Kahramanın Yokluğu. Çev., Avi Pardo. İstanbul: Parantez Yayınları. 2015.

Canetti, Elias. İnsanın Taşrası. İstanbul: Payel Yayınevi, 2011.

David Harvey. Postmodernliğin Durumu. Çev., Sungur Savran. İstanbul: Metis Yayınları, 1999.

Gürbilek, Nurdan. Yer Değiştiren Gölge. İstanbul: Metis Yayınları, 1995.

Han, Byung-Chul. Yorgunluk Toplumu. Çev., Samet Yalçın. İstanbul: Açılım Kitap, 2015.

Lefebvre, Henri. Modern Dünyada Kültürel Hayat. Çev., Işın Gürbüz. İstanbul: Metis Yayınları, 2010.

Lefebvre, Henri. The Urban Revolution. Minneapolis: The University of Minnesota Press, 2003.

Nietzsche, Friedrich. Deccal Sahte İsa. Çev., Yusuf Kaplan. İstanbul: Külliyat Yayınları, 2017.

Özdenören, Rasim. Kent İlişkileri. İstanbul: İz Yayıncılık, 2015.

Simmel, Georg. Bireysellik ve Kültürr. Çev., Tuncay Birkan. İstanbul: Metis Yayınları, 2009.

Simmel, Georg. Modern Kültürde Çatışma. Çev. Tanıl Bora, Utku Özmakas, Nazile Kalaycı, Elçin Gen. İstanbul: İletişim Yayınları, 2015.

Tuan, Yi-Fu. Bir Kurucu Unsur olarak Kaçıs. Çev., Şevket Emek Ataman. İstanbul: Litera Yayıncilık, 2015.

Žižek, Slavoj. İdeolojinin Yüce Nesnesi. Çev., Tuncay Birkan. İstanbul: Metis Yayınları, 2011. 


\title{
The Sociology of Escaping from the City and Going far away in the Modern Culture
}

\author{
SERTAÇ TIMUR DEMIR
}

\begin{abstract}
This article focuses on the nature that has turned into a kind of salvation recipe in recent years through bodily, temporal and spatial experiences. The modern individual who once desired urban-style life now gets bored of it and embarks on new quests. Today the centre of the orientation is nature. In this sense, it is high time to debate the story of returning that take places on distant geographies because the expectations of those who migrated to big cities with dreams have been tested, then they had disappointments and once left villages started to be missed again after years. In this context, the nature and province as the place of past and memory are conceived as untouched and intact and as an absolute antithesis of the city. The main question that rises here is whether or not the virgin and purified nature is excluded by the modern society figuration that centralises the urbanisation. In other words, is escaping to the nature or returning the province a permanent solution or temporary solace? All these ambivalent questions constitute the framework of this study.
\end{abstract}

Keywords: Modernity, Culture, Nature, City, Escape. 